Revista Latinoamericana de Política Comparada

ISSN: 1390-4248 • julio $2013 \bullet$ Volumen No. 7

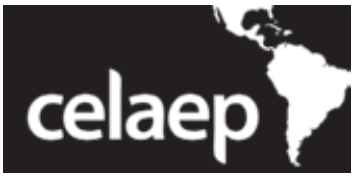

Fundación

Hanns

Seidel 


\section{Revista \\ Latinoamericana de Política Comparada}

Volumen 7, julio 2013

ISSN: 1390 - 4248

www.politicacomparada.com

info@politicacomparada.com

La Revista Latinoamericana de Política Comparada es una publicación semestral del Centro Latinoamericano de Estudios Políticos CELAEP. Las opiniones vertidas en sus páginas son de exclusiva responsabilidad de sus autores. El CELAEP y la Revista como tal, así como las instituciones de la cual forman parte los respectivos autores, no asumen responsabilidad por los criterios vertidos en la misma.

Editor de la Revista

Sebastián Mantilla Baca, CELAEP (EC)

Asistente Editorial

Carolina Ponce

Consejo de Redacción

Javier Oliva-Posada, UNAM (MX)

Daniel Zovatto, IDEA (CR)

Simón Pachano, FLACSO (EC)

Andrés Mejía, IDS (UK)

Fernando Tuesta, PUCP (PE)

Flavia Freidenberg, Universidad de Salamanca(ES)

\section{Consejo Editorial Internacional}

Klaus Bodemer, CEISAL / Universidad

de Hamburgo (ALE)

John Carey, Dartmouth

University (USA)
Josep M. Colomer, CSIC, (ES)

Richard S. Conley, University of

Florida - Gainesville (USA)

Olivier Dabène, Sciences Po (FR)

David Held, London School of

Economics and Social Sciences (UK)

Scott Mainwaring, Notre Dame

University (USA)

Cynthia McClintock, George

Washington University (USA)

María Victoria Murillo, Columbia

University (USA)

Dieter Nohlen, Universidad de

Heidelberg (ALE)

Aníbal Pérez-Liñán, Universidad de Pittsburgh (USA)

Adam Przeworski, New York University (USA)

David Recondo, CERI / Sciences Po (FR)

David Scott Palmer, Boston University (USA)

Arturo Valenzuela, Georgetown

University (USA)

Laurence Whitehead, Oxford University (UK)

Esta revista es una publicación del Centro

Latinoamericano Estudios Políticos, CELAEP

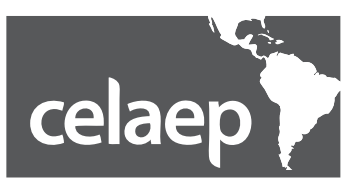

\section{Centro Latinoamericano de Estudios Políticos}

Tamayo N24-283 y Lizardo García Edif. Matisse, Piso 8, Oficina 22

Telefax: (593-2) 500-6189

P.O. BOX: 17-07-9651

Quito, Ecuador

Web: www.celaep.org

E-mail: revista@celaep.org 


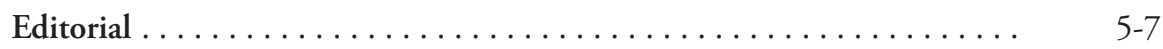

PARTE I:

Perspectivas teóricas:

Presidencialismo y Parlamentarismo

Los peligros del presidencialismo . . . . . . . . . . . . . . . . . .

Juan J. Linz

Juan J. Linz: presidencialismo y democracia.

Una revisión crítica ........................... 33-60

Scott Mainwaring y Matthew S. Shugart

Presidencialismo versus parlamentarismo.

Dos enfoques contrapuestos......................... $\quad 61-76$

Dieter Nohlen

PARTE 2:

OríGENES DEL PRESIDENCIALISMO

en Estados Unidos y América Latina

Elected Kings with the Name of Presidents.

On the Origins of Presidentialism in the

United States and Latin America . . . . . . . . . . . . . . . . . . . . .

Josep M. Colomer 
American Kingship?

Monarchical Origins of Modern Presidentialism . . . . . . . . . . . 99-126

William E. Scheuerman

Los orígenes del presidencialismo en América Latina:

un estudio sobre el proceso constituyente

argentino (1853-1860)

$127-168$

Gabriel L. Negretto

PARTE 3:

RESEÑAS BIBLIOGRÁFICAS

La identidad en democracia

Francisco Huerta M.

Presidencialismo semi-soberano .

María Victoria Ramírez

Nuevas instituciones de democracia participativa

en América Latina: La voz y sus consecuencias . . . . . . . . . . . . . . . . 175-176

Carol Landázuri

La calidad de la democracia:

perspectivas desde América Latina

Estefanía Ortiz 


\title{
American Kingship? Monarchical Origins of Modern Presidentialism
}

\author{
William E. Scheuerman*
}

\begin{abstract}
:
The modern obsession with executive charisma, especially in the context of the presidentialism variety of liberal democracy, is commonplace. This obsession derives from the oftentimes overlooked monarchical origins of the modern presidential executive. The presidential executive is outfitted with some of the awesome powers of European kingship, but it is no longer able to justify those powers on the basis of traditional religious ideas. Charisma serves as a functional replace for religiously inspired ideas of divine monarchy. Special attention is paid to the role of Alexander Hamilton in the transformation of traditional monarchist political theory into the theoretical underpinnings of the American presidency.
\end{abstract}

Keywords: executive charisma, modern presidentialism, presidential executive, religious ideas, monarchy, theoretical transformation.

\section{Resumen:}

La obsesión moderna por el carisma del ejecutivo, especialmente en el contexto de la variedad presidencial en la democracia liberal, es un lugar común. Esta obsesión se deriva de los orígenes monárquicos, a menudo pasados por alto, de la presidencia ejecutiva moderna. El ejecutivo presidencial está equipado con algunos de los poderes extraordinarios de la monarquía europea, pero ya no es capaz de justificar esos poderes sobre la base de ideas religiosas tradicionales. El carisma sirve como un reemplazo funcional de las ideas de inspiración religiosa de la monarquía divina. Se presta especial atención al rol de Alexander Hamilton en la transformación de la teoría política monárquica tradicional a los fundamentos teóricos de la presidencia de Estados Unidos.

Palabras Claves: carisma del ejecutivo, presidencialismo moderno, ejecutivo presidencial, ideas religiosas, monarquía, transformación teórica.

* William E. Scheuerman is a Professor of Indiana University 


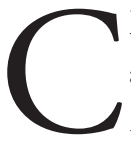
laims by political leaders to possess charisma, famously defined by Max Weber as "supernatural, superhuman, or at least specifically exceptional powers or qualities," are ubiquitous. ${ }^{1}$ In modern dictatorships, rulers often profess to master god-like magical talents, and their subjects are expected to kowtow to the boundless wisdom of the "Leader." Even in liberal democracy, where the exercise of executive power is constrained by significant political and constitutional checks, charismatic political leadership plays a notable institutional role. In presidential election years in the United States, popular political discourse is obsessed with the question of whether particular candidates "have that special something" -in short, whether they possess charismatic qualities able to satisfy the "public's wish for extraordinary leadership." 3 Presidential scholars energetically debate the question of "presidential greatness," which is often described in terms strikingly reminiscent of Weber's classical definition of charisma. ${ }^{4}$ According to an impressive body of research in political sociology, the nexus between presidential democracy and charismatic leadership is by no means coincidental. As Weber argued nearly a century ago, presidential democracy is intimately linked to the quest for charismatic political leaders: the presidential version of liberal democracy appears adept at generating a necessary dose of executive charisma in an otherwise disenchanted universe. ${ }^{5}$ More recent institutional analysts build on Weber's political intuition, arguing that presidential systems, to a greater extent than their parliamentary rivals, require would-be political leaders to show evidence of extraordinary abilities that raise them above run-of-the-mill politicians and ordinary citizens. ${ }^{6}$

An intellectual history of the origins of the modern presidential variant of the liberal democratic executive can help us make sense of the present-day fascination with executive charisma. Of course, that fascination rests on manifold roots; the liberal democratic exec-

1 Weber defined charisma as "a certain quality of an individual personality by virtue of which he is considered extraordinary and treated as endowed with supernatural, superhuman, or at least specifically exceptional powers or qualities"(Economy and Society, Vol. I, trans. Guenther Roth and Claus Wittich [Berkeley: University of California Press, 1979], 241).

2 For a discussion of this phenomenon in the context of Nazi Germany, see Franz L. Neumann, Behemoth: The Structure and Practice of National Socialism (New York: Oxford University Press, 1942), 83-97. For various attempts to clarify the (oftentimes murky) concept of charisma, as well as demonstrate its utility across political and historical contexts, see Dankwart Rustow, ed., Philosophers and Kings: Studies in Leadership (New York: George Braziller, 1970). Especially useful at both explicating and elaborating on Weber's understanding of charisma is Robert Tucker's "The Theory of Charismatic Authority," 69-94.

3 Marc Landy and Sidney M. Milkis, Presidential Greatness (Lawrence: University of Kansas Press, 2000), 2. The authors suggest that the perennial quest for presidential greatness may be "far more compatible with monarchy" than with liberal democracy.

4 Landy and Milkis, Presidential Greatness, 1-11.

5 This facet of Weber's thought is critically analyzed in Wolfgang J. Mommsen, Max Weber and German Politics, 1890-1920 (Chicago: University of Chicago Press, 1984).

6 Juan Linz, "Presidential or Parliamentary Democracy: Does it Matter?" in The Failure of Presidential Democracy, Vol. I, ed. Juan Linz and Arturo Valenzuela (Baltimore: Johns Hopkins University Press, 1994), 6-8, 2425; Bruce Ackerman, “The New Separation of Powers," Harvard Law Review 113 (2000): 658-61. I revisit this literature later in the essay. 
utive has obviously undergone omany complicated transformations in the last two centuries. One of the most important lessons of recent scholarly literature on democratization, however, is that "institutional design matters." In this spirit, I argue that the modern liberal democratic executive is more indebted to traditional monarchical conceptions of royal rule than generally acknowledged. ${ }^{7}$ Modern institutional architects of what came to be called the "executive power" by the eighteenth century broke in decisive ways with earlier religiously inspired visions of kingship. Yet they also preserved crucial elements of traditional kingship in their new theories of the executive. As I hope to show, their transfiguration of existing ideas of royal rule into the modern liberal democratic executive was complex and probably contradictory. The political and intellectual context in which early theorists of the liberal democratic executive found themselves was ambivalent, with a general decline in traditional ideas about divinely sanctioned kingship coexisting uneasily alongside attempts to preserve some of its key features. Such attempts to refurbish elements of traditional kingship can be found even among the most important theoretical influences on modern liberal democracy. I then turn to the ideas of Alexander Hamilton, a pivotal theoretician of the presidentialist variety of the liberal democratic executive, in order to buttress my intuition that the modern executive builds on traditional ideas of royal government. Hamilton's sympathy for the British monarchy has been widely noted. Less appreciated is the manner in which core features of his defense of the unitary executive borrow from traditional conceptions of kingship. In a final section, I argue that Hamilton's translation of monarchist political theory remains tension-ridden, in part because of its implicit dependence on religious conceptions of royal rule widely discredited by the American (and, later) French Revolutions. Especially in its presidentialist form, the liberal democratic executive came to be outfitted with far-reaching decision making powers. Consequently, it soon faced the unenviable task of finding a functional replacement for the divine sanction which its royal predecessor was able to draw on in order to legitimize those powers. Executive charisma represents a notable attempt to find such a functional replacement.

7 My emphasis on the monarchical origins of the presidential executive is hardly novel; it is a familiar theme in the history of political thinking about the American presidency (see Raymond Tatalovich and Thomas S. Engeman, The Presidency and Political Science: Two Hundred Years of Constitutional Debate [Baltimore: Johns Hopkins University Press, 2003]). For reasons I cannot explore here, my version of this old argument remains distinct. It is certainly more systematic than two recent polemical discussions of our "monarchical" presidency: Michael Novak, Choosing Our King (New York: MacMillan Publishing, 1974); Kevin Phillips, American Dynasty: Aristocracy, Fortune, and the Politics of Deceit in the House of Bush (New York: Viking, 2003). Please note that I rely on the term "king" because the overwhelming majority of monarchs has, of course, been male, chiefly because of sexist rules governing succession. 


\section{Kingship in Early Modern Political Thought}

Kingship is the norm in human history, and liberal democracy a rare and quite recent exception. "Kings have ruled human communities from the beginning of recorded history," and "the principle of hereditary monarchy was challenged only some two centuries ago." Around the globe as well, "for millennia, rulers rested their claims on divine sanction; other grounds of rule such as tradition or law also required and received their warrant from the divine." ${ }^{10}$ Even when theologians drew complex portrayals of the nexus between divinity and royalty, common people tended to treats kings as demigods or, at the very least, direct representatives of divine power. When we observe that monarchy has been "the preferred form of structured temporal authority across a wide band of cultures on every major continent," it becomes difficult to deny, as one recent commentator notes, that kingship "has served as an intellectually and emotionally satisfying focus" of human energies throughout the greater portion of both unrecorded and recorded history. ${ }^{11}$ Certainly, the vast scholarly literature on monarchy -as well as its distinct forms and religious justifications- provides substantial evidence that monarchy long served the emotional needs of large numbers of people. Well into modern times, "civilized" Europeans believed in the charismatic healing powers of their kings, and they flocked to see him in large numbers whenever he promised to make use of those powers to cure the ill. ${ }^{12}$ At many times and many places, the well-being of the monarch was immediately identified with the political community. People prayed for his health and prosperity because they were directly associated with the well-being of the body politic as a whole, whereas an ill or weak king foreshadowed political crisis or disorder. Moments of political transition were typically characterized by widespread anxiety, in part because of understandable concerns about the perils of monarchical succession, but also because a king's death implied that the political order as a whole had lost its chief unifying element. Well into early modern times, the king's body was seen as representing a microcosm of the body politic whose unity he alone was thought capable of constituting.

As Donald W. Hanson has observed, "it is as if all the social imponderables, all the perturbation and anxiety involved in simple societies, hovering constantly, as they do, on the edge of hunger, violence, and war, were compensated for by the idea of stable kingship." In this interpretation, "an unconscious anxiety about the endurance of social order, as well

8 Kingship has taken many different forms and relied on different modes of justification, thus making it difficult to define easily. For an important recent attempt, inspired by Weber, to capture its core elements, see Reinhard Bendix, Kings or People: Power and the Mandate to Rule (Berkeley \& London: University of California Press, 1978), 21-60.

9 Reinhard Bendix, Kings or People, 3-4.

10 Bendix, Kings or People, 7.

11 W.M. Spellman, Monarchies, 1000-2000 (London: Reaktion Books, 2000), 7.

12 Marc Bloch, The Royal Touch: Sacred Monarchy and Scrofula in England and France (London: Routledge, 1973). 
as a largely unexpressed sense of its enormous value, is the psychological truth lying behind the adulation of kings." 13 The only necessary qualification here is that the ubiquity of monarchy in human history suggests that this observation applies to many relatively complex societies as well, many of which similarly live on the "edge of hunger, violence, and war." At the intellectual level, a central thematic concern of systematic political and legal thought well into modernity, both in the West and elsewhere, has been to provide coherent structure to such unconscious and unexpressed anxieties: no less than the illiterate and uneducated, intellectuals have repeatedly looked to monarchy as a beacon of permanence and stability in a dangerous and insecure political universe. The history of political and legal thought is replete with ambitious attempts to guarantee that kingship, when properly constructed, can in fact successfully guarantee the permanence and stability of which only it purportedly was capable.

Of course, as we all recall from our school textbooks, the American and French Revolutions broke decisively with this tradition. Building on earlier historical and intellectual precedents (the Dutch Revolts, English Civil War, Glorious Revolution, subterranean republican ideas as well as the European Enlightenment), the eighteenth-century revolutionaries jettisoned hereditary monarchy for an elected executive accountable to the people and their elected representatives. They also discarded notions of divine rule, paving the way for the principle that any citizen, as long as he (and ultimately she) meets certain minimal tests (for example, having reached the age of thirty-five years) hypothetically might come to occupy the office of the executive. The hitherto virtually universal notion that kings should rule because they alone possessed superior divinely based wisdom and moral prudence went out the window as well. From now on, liberal democracies would try to figure out how best to structure political institutions so as to generate competent and intelligent holders of executive power, but no longer did they presuppose the traditional view that superior wisdom or prudence inheres in the bloodlines of the royal family or could be established via acts of consecration. In order to establish the principle of popular sovereignty, revolutionaries from Cromwell to Robespierre were driven to chop off royal heads, thereby providing a vivid, albeit rather bloody, symbol of their heroic victory over monarchical rule. ${ }^{14}$ But in exchange, we no longer treat our executives as demigods: U.S. chief executives are addressed with the modest title of "Mr. President," and when the electorate no longer desires their leadership services, they can be unceremoniously replaced in national elections. To be sure, many additional institutional transformations were necessary before

13 Donald W. Hanson, From Kingdom to Commonwealth: The Development of Civic Consciousness in English Political Thought (Cambridge: Harvard University Press, 1970), 71-72.

14 Michael Walzer, "Regicide and Revolution," in Regicide and Revolution: Speeches at the Trial of Louis XVI (New York: Columbia University Press, 1992), 1-92. 
the modern liberal democratic executive took its present-day form. Yet the shifts wrought by the American and French Revolutions nonetheless proved far-reaching: fundamental principles of political and legal equality became ensconced in the modern constitutional order, and notions of hereditary right soon belonged to the past.

Much can be said in favor of this familiar story. Unfortunately, it conveniently ignores the messier realities of eighteenth-century political and intellectual life. In light of the predominance of monarchical notions of rulership well into the eighteenth century, it should come as no surprise that the liberal democratic break with earlier ideas about monarchy proved more contradictory than popular myth lets on.

Recall the basic political realities of eighteenth-century Europe. As Leonard Krieger points out, "it was an age of kings." From the perspective of even the most astute contemporary observer, kingship could hardly have appeared historically anachronistic or even fragile: "never before had so much effective power accompanied the prestige of kingship and never again would this power prevail with so little resistance as in the half century that spanned the last years of the seventeenth century and the first part of the eighteenth century." ${ }^{15}$ In contrast to earlier periods of instability in the history of European royalty, kingship had apparently solidified its monopoly over political life by 1750 , and with a few minor exceptions (for example, the Swiss cantons), some form or another of divinely sanctioned kingship dominated the political scene. Until the very end of the century, the intellectual hegemony of monarchical ideas remained unchallenged as well. It is noteworthy that the American colonists tended to blame parliament and government ministers for the tensions that drove them away from Great Britain in the 1770s, while looking (in vain, it turned out) to the crown as a prospective savior against the corrupt and shortsighted political forces allegedly responsible for their ills. Only during the American Revolution did antipathy to monarchy become widespread. Under the Articles of Confederation, however, a growing number of voices called for the establishment of an identifiably American monarchy; prominent political observers, including Alexander Hamilton, interpreted this revival of royalist sympathy in a positive light. ${ }^{16}$ In a similar vein, the French Constitution of 1791 not only salvaged the crown but also preserved at least some of its earlier preeminence (for example, by granting it the right to veto legislation). Prominent French writers, including Emmanuel Sieyes, fought long and hard to protect the monarchy in the face of growing anti-monarchical tendencies. Indeed, with the exception of Rousseau, the most important theoretical influences (Charles Louis de Secondat Montesquieu, J.L. De Lolme, William

15 Leonard Krieger, Kings and Philosophers, 1689-1789 (New York: Norton, 1970), 1.

16 Forrest McDonald, The American Presidency: An Intellectual History (Lawrence: University of Kansas Press, 1994), 98-159; Louise B. Dunbar, A Study of Monarchical Tendencies in the United States, From 1776 to 1801 (Urbana: University of Illinois Press, 1920). I say more about Hamilton in just a moment. McDonald's study on the American presidency is rich and informative but also insufficiently critical. 
Blackstone) on the 1791 Constitution were arguably all outspoken proponents of a conservative interpretation of British-style constitutional monarchy in which the king was depicted as maintaining significant decision-making authority. ${ }^{17}$

To be sure, late seventeenth and eighteenth-century intellectuals widely satirized the more extravagant claims of Absolutist rulers. Yet most who did so remained fundamentally enamored of monarchical ideas. In many cases, they merely sought to ward off or replace continental Absolutism with the limited monarchy best represented in their eyes by post-1688 Great Britain. Their stylization of British experience deposited more authority in royal hands than soon accorded with historical reality, however. John Locke attacked Filmer's patriarchal conception of divine right in his Second Treatise, yet his reformulation of the traditional idea of prerogative authority left the door open, especially in foreign affairs, to far-reaching royal discretion. Whereas many of Locke's fellow Whigs were already struggling to make the king's traditional authority to declare and wage war directly subject to parliamentary oversight, Locke placed foreign policymaking squarely in royal hands. ${ }^{18}$ Montesquieu's conception of monarchy was no less expansive. Montesquieu blamed the ancients' hostility to monarchy on their failure to understand its proper form, which he famously saw as best embodied in the British Constitution. He not only assumed that executive power was best exercised, as in Britain, by a monarch, but offered an interpretation of the British system that undoubtedly exaggerated the king's actual power by the mid-eighteenth century. Whereas the British crown had already ceased to exercise an effective veto by the beginning of the eighteenth century, and parliament was increasingly gaining the upper hand in overseeing foreign as well as domestic affairs, Montesquieu outfitted his executive with a veto over legislation, while following Locke in arguing for its absolute supremacy in foreign policy. ${ }^{19}$ The principle of the separation of powers called for a powerful independent monarchy; in Montesquieu's theory, a stylized and historically anachronistic interpretation of the British crown worked adeptly to perform the requisite functions.

A similar pattern can be detected among lesser known eighteenth-century writers who came to exert a profound influence on American and French political opinion. ${ }^{20}$ The great English theorist of "mixed government" and possible intellectual inspiration for Montes-

17 See the classic German-language study by Robert Redslob, Die Staatstheorien der franzoesischen Nationalversammlung von 1789 (Leipzig: Veit, 1912), 221-83.

18 John Locke, Second Treatise of Government, Chapter 12, Chapter 14 [1681]. For a discussion, see John Dunn, The Political Thought of John Locke: An Historical Account of the Argument of the Two Treatises of Government (Cambridge: Cambridge University Press, 1969), 148-64.

19 Montesquieu, Spirit of the Laws, ed. Anne Cohler (Cambridge: Cambridge University Press, 1989 [1748]), 156-68.

20 According to McDonald (The American Presidency: An Intellectual History, 38-66), Locke, Montesquieu, Bolingbroke, De Lolme, Hume, and Blackstone constitute the most significant influences on early American thinking about the executive. 
quieu's doctrine of the separation of powers, ${ }^{21}$ Henry St. John Bolingbroke, proudly declared that "I am not one of those oriental slaves, who deem it unlawful presumption to look their kings in the face." 22 Yet he simultaneously fantasized about the prospects of a powerful "patriot king," an enlightened reformer-from-above, able to employ a formidable array of powers in order to rejuvenate British political life and better guarantee political unity. Despite his forceful criticisms of divine right, Bolingbroke ultimately endorsed a rather traditional paternalistic vision of the monarch as a wise "shepherd" essential to the leadership and unity of his herd: a patriot king would be "like the common father to the people," while "the true image of a free people, governed by a Patriot King, is that of a patriarchal family." ${ }^{3}$ The Genevan monarchist De Lolme, cited appreciatively by Hamilton in Federalist 70 and a deep influence on French thought in 1789, memorialized the "healthy equilibrium" of the English system for maintaining both a vigilant parliament and powerful independent executive, whose unitary character was best preserved by remaining in the hands of the single person of the monarch. Although no friend of royal Absolutism, De Lolme saw the chief danger to English liberty as deriving from parliament's tendency to usurp traditional royal prerogatives, and thereby undermine the "only self-existing and permanent power of the state." ${ }^{24}$ Following Montesquieu's stylized model of the separation of powers, De Lolme warned of the perils of an ominous fusion of legislative and executive power under parliamentary auspices. While anticipating Hamilton's famous argument that the unitary character of the executive best rendered it accountable to popular preferences, De Lolme insisted that only a king in possession of significant independent decision-making resources could provide an effective check on numerous popular assemblies as well the dangerous popular demagogues spawned by them. In this scheme, the unitary character of the (monarchical) executive allowed the people and their representatives to check the danger of Absolutist excesses. For De Lolme, as for Montesquieu before him, the separation of powers called for a politically puissant monarch.

In a similar fashion, intellectuals widely spoofed the religious pretensions of royal Absolutism, while simultaneously struggling to preserve something of the "dignity" which traditional justifications for monarchical prerogative had once helped provide. Locke and Bolingbroke attacked religious groundings for Absolutist rule, yet both ultimately defended powerful royal executives on the basis of Christian natural law; in the final analysis, both

21 Robert Shackleton, Montesquieu: A Critical Biography (Oxford: Oxford University Press, 1961), 296-301.

22 Henry St. John Bolingbroke, AThe Idea of a Patriot King,@ in The Works of Lord Bolingbroke, Vol. II (London: Frank Cass, 1967 [1738]), 372. On Bolingbroke, see Isaac Kramnick, Bolingbroke and His Circle: The Politics of Nostalgia in the Age of Walpole (Cambridge: Harvard University Press, 1968).

23 Bolingbroke, AIdea of a Patriot King,@ 401

24 J.L. De Lolme, The Constitution of England (London: Henry Bohn, 1853 [1784]), p. 194; on the dangers of legislative supremacy, see 69, 317-24. Although exerting an enormous influence on Hamilton, De Lolme has been neglected by scholarship on the U.S. presidency. 
refurbished kingship's religious foundations. ${ }^{25}$ David Hume spoke for many of his learned contemporaries in the second half of the century when he commented, "to talk of a king as God's vice regent on earth, or to give him any of those magnificent titles, which formerly dazzled mankind, would but excite laughter in every one." ${ }^{26}$ However, he also observed that monarchies still receive "their chief stability from a superstitious reverence to priests and princes." ${ }^{27}$ Apparently, Hume only had the educated public in mind when he spoke of "every one": as he correctly understood, a religiously derived reverence for the dignity of the monarch still functioned in the eighteenth-century to guarantee political legitimacy and preserve stability. Although no friend of divine right, De Lolme similarly praised the British for preserving the idea of a "sacred and inviolable" monarch "not to be addressed but with all the expressions and outward ceremony of almost Eastern humility," and in possession of "all the personal privileges, all the pomp, all the majesty, of which human dignities are capable." 28 Perhaps it was acceptable if fellow intellectuals such as Bolingbroke or Hume refused to acknowledge the backwards superstitions of monarchical pomp. Yet it was best if most others continued to do so: even though no longer in fact a divine viceregent, only a monarchical executive outfitted with the requisite majesty and dignity could guarantee an effective independent executive and thereby preserve balanced government.

Among those skeptical of divine justifications for royal rule yet convinced of its political utility, Blackstone perhaps best captured the paradoxes at hand when he observed that though a philosophical mind will consider the royal person merely as one man appointed by mutual consent to preside over many others, and will pay him that reverence and duty which the principles of society demand, yet the mass of mankind will be apt to grow indolent and refractory, if taught to consider their prince as a man of no greater perfection than themselves. The law therefore ascribes to the king, in his high political character, not only large prerogatives and emoluments which form his prerogative and revenue, but likewise certain attributes of a great and transcendent nature; by which the people are led to consider him in the light of a superior being, and to pay him that awful respect, which may enable him with greater ease to carry on the business of government. ${ }^{29}$

In his Commentaries, Blackstone then proceeded to group "certain attributes of a great and transcendent nature," including an impressive array of traditional royal prerogatives, under the open-ended rubric of "royal dignity." Despite understandable "philosophical" challenges to the divine sanctity of kings as a basis for their "greater perfection," Blackstone

25 For example, see Bolingbroke, AIdea of a Patriot King,@ 378-79.

26 Hume, Political Essays, ed. Knud Haakonssen (Cambridge: Cambridge University Press, 1994 [1772]), 31.

27 Hume, Political Essays, 69

28 De Lolme, Constitution of England, 147.

29 William Blackstone, Commentaries on the Laws of England, Vol. I (Chicago: University of Chicago Press, 1979 [1765]), 234. 
argued, political stability not only required a relatively powerful monarch, but he could only flourish if directly linked to "transcendent" authority. Consequently, "by law the person of the king is sacred, even though the measures pursued in his reign be completely tyrannical and arbitrary," since his transcendent character required that "no jurisdiction upon earth has power to try him in a criminal way; [sic] much less to condemn him to punishment." ${ }^{30}$

In short, by the time of the great revolutions of 1776 and 1789, educated Europeans were increasingly unconvinced by conventional religious justifications for divine rule. But monarchy, which they typically deemed the only legitimate government, required legitimization via some variety of divine sanction, if only for popular consumption. ${ }^{31}$ In Weberian terms: notwithstanding the ongoing disenchantment [Entzauberung] of royal authority, those astute enough to recognize the virtues of a stable monarch were also supposed to grasp the need to preserve the institutional practices traditionally associated with "royal dignity" in order to make sure that most people continued to view their kings as "superior beings." Popular thinking was simply too crude and unrefined to do without the necessary fiction of divine monarchy, and the emotional needs satisfied by the belief in divine royalty simply too weighty. Although occasionally hinting at the possibility of a thoroughgoing secularization of executive power, influential political thinkers typically saw this prospect as destined to pave the way to anarchy and disorder.

\section{Alexander Hamilton and the Monarchical Origins of the American Presidency}

The case of Alexander Hamilton -one of modern liberal democracy's most significant theoreticians of executive power- provides a revealing illustration of how conflict-laden ideas about executive power helped generate a correspondingly tension-ridden liberal democratic executive. A participant in the pervasive Anglophilia of eighteenth-century enlightened opinion, Hamilton's view of the British monarchy was overwhelmingly positive, and his writings include many idealized portrayals of its operations. Like Montesquieu and other earlier defenders of the British monarchy, Hamilton tended to downplay the extent to which Britain was already being transformed into modern parliamentary government. Accordingly, he followed De Lolme in worrying that parliament was aggressively stripping the crown of too many of its traditional prerogatives. ${ }^{32}$ Reminiscent of Hume and Blackstone,

30 Blackstone, Commentaries on the Laws of England, Vol. I, 235.

31 The great exception to the general embrace of monarchy was Tom Paine.

32 See Federalist 69 (The Federalist Papers, ed. Clinton Rossiter [New York: NAL Penguin, 1961], 419-20), where Hamilton notes that "it has been [falsely] insinuated" that the king's treaty-making authority is "subject to the revision, and stands in need of the ratification, of Parliament. But I believe this doctrine was 
Hamilton does not seem to have held religious justifications for monarchy in high regard. Nonetheless, as one of George Washington's closest advisors during the first American presidency, he would undertake to salvage at least some of the executive "majesty" and "dignity" traditionally associated with royal rule. ${ }^{33}$ In accordance with his theoretical predecessors, Hamilton understood that by the end of the eighteenth century the conceptual underpinnings of kingship were in shambles. Yet he worried that the end of the "age of kings" would herald an age of disorder and foreign wars in which "the amazing violence and turbulence of the democratic spirit" were left unrestrained. ${ }^{34}$ Not surprisingly, his influential model of the American presidency ultimately rests on an impressive attempt to reformulate traditional monarchist political ideas.

In a revealing June $18^{\text {th }}$ speech that outlines much of Hamilton's political and intellectual agenda in 1787, Hamilton announced to the Philadelphia Convention that the British constitution was "the best in the world" since it is the only government uniting "public strength with individual security." ${ }^{35}$ In his view, only the British had been able to preserve both liberty and stability. Accordingly, much of Hamilton's intellectual and political energy was devoted to trying to show his colleagues at the Convention that American nationhood -a new "republican empire," as one commentator has underscored ${ }^{36}$ - required significant borrowing from the most desirable facets of British experience. In Hamilton's eyes, those advantages were numerous. As a political realist, Hamilton understood that republican sympathies in the American states prevented the open reestablishment of a British-style monarchy. Given the Americans' republican instincts, "he was sensible...that it would be unwise to propose one of any other form." ${ }^{37}$ However, the increasingly self-evident disorders of republicanism under the Articles of Confederation "led him to anticipate the time, when others as well as himself would join in the praise" of the British government,

never heard of until it was broached upon the present occasion." Hamilton cites (the rather conservative) Blackstone as support. Also, in Federalist 73 (444), Hamilton concedes that the British crown had not used its "negative" for a lengthy period of time, yet seems to see this as a strategic choice on the crown's part rather than as evidence of significant institutional shifts.

33 The inauguration ceremony and state of the union address, for example, were modeled on British practice (McDonald, The American Presidency: An Intellectual History, 214-18).

34 Hamilton, "Speech in the Constitutional Convention on a Plan of Government" (Version recorded by James Madison, in Hamilton, Writings, 157.) Madison's notes on Hamilton's address correspond to Robert Yates's (Hamilton, Writings, 159-66). Hamilton was not along among the framers in harboring deep respect for monarchy; think, for example, of John Adams. However, his ideas exercised undeniable influence on the U.S. presidency, and thus are examined in detail here. For an excellent concise survey of the intellectual backdrop to the framers' ideas about the presidency, Jack N. Rakove, Original Meanings: Politics and Ideas in the Making of The Constitution (New York: Knopf, 1996), 244-87. Rakove neglects the extent to which the framers' ideas built on longstanding ideas about monarchy.

35 Hamilton. "Speech in Convention," 156.

36 Karl-Friedrich Walling, Republican Empire: Alexander Hamilton on War and Free Government (Lawrence: University of Kansas Press, 1999).

37 Hamilton, "Speech in Convention," 156. 
and especially its hereditary monarch, "the only good" model of executive power, Hamilton bluntly told a surprised Convention, in the entire world. ${ }^{38}$ Repeating a commonplace monarchist defense of hereditary rule, Hamilton observed that "the Hereditary interest of the King was so interwoven with that of the Nation, and his personal emoluments so great, that he was placed above the danger of being corrupted from abroad." ${ }^{39}$ For this reason, the British monarchy regularly proved adept at warding off political instability and foreign threats, and because good government is simply impossible without an effective executive, the crown represented a central source of British political greatness. Paraphrasing De Lolme, Hamilton went on to praise the English monarchy for being "sufficiently independent and sufficiently controlled, to answer the purpose of the institution at home" as well as abroad, before arguing that the great programmatic task before the Convention consisted in figuring out how a British-style monarch could be recalibrated in accordance with the anti-monarchical political preferences of post-1776 America. Otherwise, the "stability and permanency" intrinsic to hereditary monarch would be lost, and the new American states, like earlier experiments in popular government, would be "liable to foreign influence and corruption" and destined to fail. ${ }^{40}$ Hamilton admitted that the institutional puzzle at hand was demanding and perhaps unsolvable: "as to the executive, it seemed to be admitted that no good one could be established on republican principles." ${ }^{41}$ How then might the American republic ever institutionalize a satisfactory executive? Hamilton's answer seems to have been that it could only do so by borrowing substantially from traditional monarchist ideas.

Hamilton proposed to the Convention delegates that executive power be vested in a supreme governor, selected "by Electors chosen by electors chosen by the people," for life, or at least "during good behavior." ${ }^{2}$ Monarchical stability and permanence might be placed on new footing, since an executive-for-life, Hamilton argued, would be less subject to the foreign intrigues and conspiracies that had plagued the history of republicanism: an executive-for-life "will be a safer depository of power" than one with a limited term of office because he lacks any incentive to try to prolong his stay in power by availing himself of war or instability. ${ }^{43}$ In accordance with contemporary Anglophile theories of the British system, though by no means British political reality, Hamilton's executive would also have a veto or "negative" on all laws as well as the power to pardon. He was to possess "the direction of war, when authorized or began" by the legislature, and would pursue foreign policy

38 Hamilton, “Speech in Convention,” 156-57. See also “Letter to George Washington, July 3, 1787," Writings, 166-67.

39 Hamilton, "Speech in Convention," 157; Federalist 22, 149. Thomas Hobbes, for example, made a similar point in his defense of monarchy (Leviathan, Part II, Ch. 19).

40 Hamilton, "Speech in Convention," 157.

41 Hamilton, "Speech in Convention," 157.

42 Hamilton, "Plan of Government," in Writings, 149.

43 Hamilton, "Speech in Convention," 158. 
with the advice and consent of an upper house whose members, like the House of Lords, would be chosen for life. In anticipation of the criticism that his proposal was ultimately inconsistent with republican principles, Hamilton responded: "But is this a Republican Government, it will be asked? Yes, if all the Magistrates are appointed, and vacancies are filled, by the people, or a process of election originating with the people." ${ }^{44}$ If republicanism is chiefly characterized by a commitment to the popular election of magistrates, then an executive chosen, however indirectly, by the people and their representatives for life, can be fairly described as republican.

Hamilton's argument relies on a truncated interpretation of the republican political tradition; ${ }^{45}$ Hamilton himself seems to have realized that his initial rejoinder was likely to be deemed insufficient by his peers. As he quickly conceded, a hereditary crown was only one of the more familiar varieties of monarchical government, and a system of one-person (monarchical) rule might also be established by some method of election. Indeed, as Hamilton probably knew, something along these lines may have existed in the distant European past. ${ }^{46}$ Hamilton then proceeded to admit that his proposal might aptly be described as "an elective monarch." But this, he soon added, should generate no special anxiety. "It had been observed by judicious writers that elective monarchies would be the best [governments] if they could be guarded against the tumults excited by the ambition and intrigues of competitors. He was not sure that tumults were an inseparable evil." Hoping that the Americans might avoid them, he added the rhetorical question: "Might not such a mode of election be devised among ourselves as will defend the community against these effects in any dangerous degree?" 47 In any event, "monarch is an indefinite term," Hamilton insisted, notwithstanding his own repeated appeals to it in his flattering references to the British crown. For the hard-headed Hamilton, vastly more important than philosophical disputes about the proper definition of "monarchy" or "republic" was the eminently practical task of preserving monarchys historical achievements in the context of the American "republican" commitment to "a practice of election originating in the people." Hamilton's impatience with fundamental theoretical questions undoubtedly played a key role in paving the way for his intellectually eclectic attempt to fuse monarchy with republicanism.

44 Hamilton, "Speech in Convention," 157

45 Traditional republican ideals of participation, for example, or a robust conception of the common good, are missing here.

46 Some form of election may have characterized "Germanic" kingship, an influence on early English monarchy. Se Fritz Kern, Kingship and Law in the Middle Ages (New York: Harper, 1956), xix, 7, 47-9. Medieval thinkers such as Marsilius of Padua also defended the election of kings as a way of guaranteeing their preeminence and virtue.

47 Hamilton, "Speech in Convention," 158. Many of Hamilton's subsequent reflections in Federalist 68, accordingly, are devoted to a defending the electoral college. 
Hamilton's June $18^{\text {th }}$ proposal for an executive-for-life was quickly rejected by the Convention. Hamilton tended to look askance at much of its subsequent proceedings in part because of the delegates' failures to accept his appreciative portrayal of monarchical government. He seems to have considered the proposals for a national executive ultimately hammered out by the Convention as a necessary but probably unfortunate compromise, notwithstanding his eloquent defense of them in The Federalist. ${ }^{48}$ Perhaps this also helps explain his heated polemics against those who subsequently criticized the more palatable vision of executive power finalized by the Philadelphia Convention. In describing his own executive-for-life, Hamilton told the Convention in June that "he was sensible that an executive constituted as he proposed would have in fact but little of the power and independence that might be necessary." ${ }^{39}$ After all, it still lacked many of the most striking features of British hereditary monarchy. When faced with later critics of the Convention's own pale imitation of Hamilton's "elected monarch," Hamilton, not surprisingly, lashed out in Federalist 67 at the "talent for misrepresentation" which led them to claim that the Convention's delegates had voted to reestablish British-style monarchy. ${ }^{50}$ Hamilton was correct that the proposed American presidency was no carbon copy of his beloved British crown; in responding to those who made this claim, he later joined with Madison and Jay to develop a richer account in The Federalist than proffered in his June speech not only of the essence of republican government, but of why the proposed "chief magistrate" possessed republican credentials. The Federalists did not undertake simply to reestablish monarchy, as Anti-Federalists and later critics such as Jefferson who saw Hamilton as the ringleader of a dangerous monarchist conspiracy, asserted..$^{51}$ However, it would be mistaken to conclude that the specter of monarchy was thereby fully purged from the proposed American presidency. Too many of its core features were inspired by a stylized interpretation of the British monarchy not only

48 On September 6, as the Convention's deliberations were coming to a close, Madison reports that "Mr. Hamilton said that he had been restrained [after making his ill-fated proposals in mid-June] from entering into discussions by his dislike of the scheme of government in general [its republican structure?]; but... he meant to support the plan to be recommended, as better than nothing" (589). On September 17 ${ }^{\text {th }}$, Hamilton called for every member of the Convention to endorse the document, pointing out to his colleagues that "no man's ideas were more remote from the plan than his were known to be [!]; but is it possible to deliberate between anarchy and convulsion on one side, and the chance of good to be expected from the plan on the other" (656) (Madison, Notes of Debates in the Federal Convention of 1787 Reported by James Madison (Athens: Ohio University Press, 1966).

49 Hamilton, Speech in Convention, 157

50 Federalist 67, 407.

51 For Hamilton's responses to this accusation, see Writings, 749- 50, 781-94. The accusation is too crude, since Hamilton ultimately accepts the necessity of some form of republican government for the United States. The more interesting question is whether his ideas about the executive helped smuggle monarchical elements into the U.S. constitutional system. Revealingly, even when replying to such critics (for example in a letter written on May 26, 1792), Hamilton insists that "it is yet to be determined by experience whether it [republican government] be consistent with that stability and order in Government which are essential to public strength $\&$ private security and happiness" (Writings 750 ). For Hamilton, as for countless defenders of monarchy before him, stability and order were monarchy's greatest strengths. 
openly eulogized by Hamilton, but whose actual operations constituted the general horizons of the vast proportion of political experience for the delegates who gathered in Philadelphia.

Most recent scholarship underlines the fact that the Convention discarded Hamilton's June proposals. ${ }^{52}$ However, it tends to downplay the fact that some of its key features ultimately made their way into the final product. ${ }^{53}$ The highly indirect mode of election of the executive was realized in the Constitution, as was the executive veto and pardon power. Hamilton's characterization of the "weak" (traditional) republican executives found under the Articles of Confederation as an unabated disaster became the starting point for the Convention's own reflections on reforming executive power. Just as Hamilton proposed, foreign policy was ultimately shared between the executive and a second legislative house whose members were expected to serve for a longer term of office than those in the first house. ${ }^{54}$ Hamilton's general vision of what soon became the U.S. Senate, as well as its relationship to the executive, undoubtedly influenced the Convention's final product. Contemporary scholarship also concurs with the assessment that some key powers of the American presidency (in particular, the executive veto) build on the idealized portrayal of the British crown proffered by Anglophile authors like Montesquieu, De Lolme, and Hamilton. ${ }^{55}$ On a more controversial note, commentators have also asserted that the expansive interpretation of the idea of executive power defended by Hamilton in The Federalist Papers, and then in his activities as a leading Federalist politician, was intended to include extensive prerogative powers, especially in foreign policy, along the lines Locke attributed to the British crown even after 1688. In this view, Hamilton's theoretical achievement was to overcome the Lockean dichotomy between (supra-legal) prerogative and strict legality by conceiving of the (legal) authority of the executive in dynamic and thus potentially alterable terms. ${ }^{56}$ Although rightly subject to scholarly dispute, this interpretation at least does justice to Hamilton's repeated insistence on a flexible reading of executive power clauses of the U.S. Constitution, ${ }^{57}$ as well as the unabashedly vast discretionary powers in

52 Ray Raphael, Mr. President: How and Why the Founders Created a Chief Executive (New York: Alfred Knopf, 2012).

53 For an exception, see Landy and Milkis, Presidential Greatness, 15.

54 At first glance, this represents a significant break with the British monarchy, as Hamilton repeatedly claims in The Federalist Papers, at least if we accept conservative idealizations of the English monarchy (for example, in Montesquieu) at face value. However, if we recall the growing power of the British parliament in foreign policy even in the eighteenth century, the comparison becomes more complicated.

55 See Robert J. Spitzer, “The President's Veto Power," 156-60; David Gray Adler, “The President's Pardon Power," 212-18, both in Inventing the American Presidency, ed. Thomas Cronin (Lawrence: University of Kansas Press, 1989).

56 Harvey C. Mansfield, Taming the Prince: The Ambivalence of Modern Executive Power (Baltimore: Johns Hopkins University Press, 1989), 247-78, esp. 255-56. For reasons that should become clear later in this essay, I believe that Mansfield overstates the Machiavellian origins of modern executive power.

57 In Federalist 28, for example, Hamilton writes that during an emergency, "Athe means to be employed must be proportioned to the extent of the mischief" (178). 
foreign policymaking he attributed to President Washington in a famous debate with James Madison in 1793, who by no means unfairly accused Hamilton of having uncritically accepted royalist ideas of prerogative. ${ }^{58}$ Whatever the precise place of free-wheeling executive prerogative in the original U.S. Constitution, during the course of American history the Hamiltonian vision of a powerful executive who acts creatively when the law is unclear or silent, and whose power expands in accordance with the dictates of a crisis or emergency situation, has undoubtedly gained many influential adherents. Although in many different respects, it has probably become the governing doctrine for many if not most U.S. presidents at least since the outset of the twentieth century. ${ }^{59}$

When read in light of his June $18^{\text {th }}$ Convention speech, Hamilton's defense of the proposed U.S. presidency in The Federalist quickly reveals the awkwardness underlying his eclectic synthesis of republicanism and monarchism. His most direct response to critics who accused him of advancing a monarchist agenda, Federalist 67, conveniently focuses on one of their most peculiar arguments, namely the suggestion that the proposed President's power of appointment might allow him to dominate the Senate. His repeated attempts in Federalist 67 and elsewhere to defuse the accusation of monarchism by favorably comparing the proposed federal presidency to the Governor of New York ignores the fact that the latter was the strongest of the state executives and itself arguably had been modeled on some features of the British monarchy. ${ }^{60}$ In his defense of the electoral college in Federalist 68, Hamilton argues that only a complex and highly indirect mode of election can culminate in the selection of "characters preeminent for ability and virtue;" an extraordinary individual, it seems, is unlikely to be chosen by direct popular election. ${ }^{61}$ Earlier defenders of an "elective monarchy," which Hamilton had earlier described as a suitable description of his own June proposals, could easily have assented to this point. In Federalist 71, he worries

58 The Letters of Pacificus and Helvidius with the Letters of Americanus, ed. Richard Loss (Delmar, New York: Scholars' Facsimiles, 1976 [1793]), where Madison accuses Hamilton of undertaking to import a royalist conception of prerogative into the operations of the U.S. government. Commenting on Locke and Montesquieu, Madison writes: "Both of them are too evidently warped by a regard to the particular government of England, to which one of them owed allegiance; and the other professed an admiration bordering on idolatry." On Locke, Madison continues: "The chapter on prerogative shows, how much the reason of the philosopher was clouded by the royalism of the Englishman" (56). To the extent that Hamilton builds on their ideas, Madison presciently observes, he reproduces their royalist institutional agenda.

59 This trend was noted by Edward S. Corwin, The President: Office and Powers, 1787-1957, $4^{\text {th }}$ ed. (New York: New York University Press, 1957). On presidential emergency power, see the classic study by Clinton Rossiter, Constitutional Government: Crisis Government in the Modern Democracies (New Brunswick: Transaction Press, 2002 [1948]), 207-87 and, more recently, Michael A. Genovese, Presidential Prerogative: Imperial Power in an Age of Terrorism (Palo Alto: Stanford University Press, 2011).

60 After the revolution, only New York "established a chief executive office that was vested with any significant power” (McDonald, The American Presidency: An Intellectual History, 132). The New York Governor exercised a veto (which he shared with a "council of revision"), was empowered to call the legislature into session and could prorogue it for sixty days; he also possessed powers of pardon and reprieve, and was commander in chief of the New York military forces (McDonald, American Presidency, 134).

61 Federalist 68, 414. 
that the proposed four-year term of office potentially might fail to provide the executive with the requisite executive virtues, since "the longer the duration in office, the greater" the likelihood of "personal firmness" as well as the permanency and stability of administration. ${ }^{62}$ For similar reasons, Hamilton had previously argued at the Philadelphia Convention that hereditary monarchy was the only "good executive" thus far discovered by humankind. In Federalist 72, Hamilton criticizes presidential term limits in part inspired by the hope that disallowing them would permit superior leaders to serve for a lengthy duration. ${ }^{63}$ If extraordinary men can gain reelection on a number of occasions, he seems to have reasoned, some of the political permanence and stability of British hereditary monarchy could be salvaged in the American context. In his defense of the executive veto in Federalist 73, Hamilton claims that the powerful British crown's failure to make recent use of it shows that the Americans, with their republican system of government, have no reason to fear its abuse:

If a magistrate so powerful and so well fortified as a British monarch would have scruples about the exercise of the power under consideration, how much greater caution may be reasonably expected in a President of the United States, clothed for the short period of four years with the executive authority of a government wholly and purely republican? ${ }^{64}$

Yet this interpretation occludes the fact that the royal veto in Britain had been abandoned chiefly because of parliament's growing power, which Hamilton, in accordance with conservative defenders of the British balanced constitution like Blackstone and De Lolme, faced with skepticism. ${ }^{65}$ What Hamilton in fact proposed was to refurbish the U.S. executive with a remodeled royal "negative" which British political development was already well on its way to discarding. Similarly, his defense of the executive pardon in Federalist 74 mirrors traditional justifications of the superiority of one-person rule. The proposed U.S. President was likely to exercise the pardon power cautiously, Hamilton claimed, because "the reflection that the fate of a fellow creature depended on his sole fiat would naturally inspire scrupulousness and caution," whereas placing the pardon in numerous hands inevitably encourages its holders to pursue "an act of obduracy, [since they] might be less sensible to the apprehension of suspicion or censure for an injudicious or affected clemency." ${ }^{66}$ Yet if sole fiat tends towards scrupulousness, while the "rule of many" generates obduracy, why not place many other far-reaching forms of decision making authority in executive hands as well? For centuries, monarchists had made precisely this type of argument in defense of the superiority of one-person rule.

62 Federalist 71, 431; Federalist 72, 436.

63 Federalist 72, 437.

64 Federalist 73, 444.

65 See again, Federalist 69, 419-20.

66 Federalist 74, 448. 
Hamilton's now legendary defense in Federalist 70 of an energetic unitary executive as alone capable of "decision, activity, secrecy, and dispatch," as well as best able to act in a responsible and accountable manner, was intended to counter the criticism that an executive in the hands of a single person necessarily implies a preference for monarchy. ${ }^{67}$ In Hamilton's account, "whenever two or more persons are engaged in any common enterprise or pursuit, there is always the danger of difference of opinion," thereby threatening to "weaken the authority, and distract the plans and operations of those whom they divide." ${ }^{8}$ Although potentially advantageous in the legislature, such disagreement is ultimately incongruent with the effective exercise or execution of political power. The very nature of executive power implies the need to place it in the hands of a single person and then make sure that its sole carrier possesses substantial independent institutional resources; otherwise, both effectiveness and consistency in the overall exercise of political power are imperiled. Just as important, the unitary character of the executive contributes to accountability because "the public opinion is left in suspense about the real author" of state action when plurality in the executive allows its component members to shift blame and obscure their responsibility for political mistakes. ${ }^{69}$

To be sure, Hamilton's defense of the unitary executive is hardly inherently monarchical. Nonetheless, it is taken virtually verbatim from two outspoken defenders of the British crown, De Lolme and Blackstone, both of whom suggested that a monarchy along British lines alone could successfully past the tests required by an effective unitary executive. In their view, only a monarchical form of unitary executive could possess sufficient independent institutional resources, and thus help realize the principle of the separation of powers as articulated by Montesquieu and others. ${ }^{70}$ The crown's unitary and independent character, they argued, preserved a healthy balance between parliamentary legislation and royal discretion, thus warding off the ominous prospect of fused legislative and executive power, as well as permitting the crown to preserve those prerogatives essential if the populace were to continue to see the monarch as a man of "greater perfection than themselves." Hamilton's June Convention speech suggests that he generally shared this positive assessment of British experience. By the conclusion of the Philadelphia Convention, Hamilton apparently had come to believe that "the chance of good to be expected" from the proposed American presidency, though probably not as desirable as a British-style monarch, outweighed the immediate peril of "anarchy and convulsion." ${ }^{71}$ Given the structure as well as

67 In Federalist 69 (415), Hamilton summarizes this criticism.

68 Federalist 70, 425-26.

69 Federalist 70, 427-29.

70 See Hamilton'ss praise for De Lolme (Federalist 70, 430) and Blackstone (Federalist 69, 419-20). Also, De Lolme, Constitution of England, 154-6, 192-6, 253-32; Blackstone, Commentaries, 242-43.

71 Madison, Notes of Debates in the Federal Convention, 656. 
immediate provenance of Hamilton's conception of the unitary executive, however, his endorsement of the Convention's presidency probably only makes sense if Hamilton thought that it possessed a real chance to gain sufficient independent political power and prestige such that it could realistically serve as an effective counterweight, as De Lolme similarly claimed for the British crown, to "the amazing violence and turbulence of the democratic spirit." Although obviously no longer a hereditary monarchy, the U.S. President might be expected to fulfill basic monarchical functions: like its royal predecessors, it would bestow potentially far-reaching institutional influence on extraordinary individuals, outfitted with substantial power resources, who would possess a real chance at frequent reelection and thus might prove capable of preserving institutional stability and permanence in the context of ominous democratic rumblings. Like the British crown, the U.S. President might counteract the pervasive irrationality of mass (democratic) opinion.

Indeed, Hamilton's main accomplishment in Federalist 70 arguably was to legitimize the impressive powers of the U.S. presidency by reformulating familiar royalist ideas about the advantages of one-person rule. Like those of countless previous defenders of religiously grounded monarchy, Hamilton's writings are filled with nervous warnings about the potential disorders and tumults of popular government, as well as the ineptness of republics in the face of foreign threats. In Federalist 6, for example, Hamilton rejects the Enlightenment dogma that commerce and foreign trade tend towards a pacific world order: for Hamilton, international relations are inherently violent and potentially explosive, thereby necessitating the establishment of a powerful executive capable of guaranteeing a coherent and thereby efficacious mobilization of the political community's potential powers. ${ }^{72}$ Paradoxically perhaps, this brings Hamilton closer to the rather bleak portrayal of human affairs as perpetually threatened by violence and misery found in numerous medieval and early modern theorists than to the ideas of his Enlightenment contemporaries. He also echoes monarchist authors in asserting that only a unitary system of rule can provide consistency in basic decision making, or what Hamilton sometimes called "administration."

In medieval Christian defenses of kingship, for example, its superiority was regularly asserted on the basis of the view that the single person of the king alone provided the unity and coherence requisite to the effective use of political power. In this view, popular government was a recipe for dissent and discord, since (plural) groups of people inevitably disagree, and thus are incapable of generating political unity. As a result, popular government is inconsistent with consistency and overall coherence in the operations of political authority; only rule by a single person can realize them. Even more significant, nothing could be more pressing than the coherent and unified exercise of political power in a dan-

72 See Federalist 6. Hamilton also notes: "It is of the nature of war to increase the executive at the expense of the legislative authority" ( $\underline{\text { Federalist } 8,68) .}$ 
gerous and generally violent political universe. Monarchy was politically superior not only because it reproduced the unitary (Christian) divine kingship which governed the universe as a coherent whole, medieval authors argued, but also because every diverse "multitude" can only act in a cohesive manner if ultimately subject to the rule of one (unified) actor. As Aquinas observed, "a united force is more efficacious in producing its effect than a force which is scattered or divided," and the only practical way to realize a "united force" is by means of a legitimate (that is, natural law-based) system of kingly rule. ${ }^{73}$ In defense of the principle of one-person rule, William of Ockham noted in even blunter terms, "where there is not one governor the people will be ruined" 74 since

it is difficult and takes a very long time and very heavy labor and expense to assemble a general council...Therefore, so as to forestall dangers in such cases more easily, it is beneficial for the community of the faithful to have one head and prelate in power with such matters... ${ }^{75}$

For Dante, in order to pursue any given end in an efficacious manner, general direction to our activities is required. How best to assure such direction in political life? By placing the political community under the auspices of a single ruler: "otherwise its inhabitants will not only fail to achieve their end as citizens but the kingdom itself will crumble." ${ }^{76}$ Given the immense perils of conflict and discord in political life, "there has to be a judgment to settle it," and such judgments can only achieve a common structure and coherence when placed in the hands of a unitary monarch. ${ }^{77}$ Some medieval authors even anticipate the outlines of Hamilton's account of the superior accountability of a unitary executive: Ockham comments that "it is easier to get access to one than to many" in defending the virtues of one-man rule. ${ }^{78}$

It is similarly illuminating that Hamilton's obsession with executive "energy" in Federalist 70 and elsewhere echoes earlier royalist imagery. Notwithstanding the obvious centrality of this term to Hamilton's theory, scholars have had little to say about its likely genesis beyond noting its apparent origins in modern physics. ${ }^{79}$ Whatever its immediate source,

73 St. Thomas Aquinas, "On Kingship," in The Political Ideas of St. Thomas Aquinas (New York: Haner, 1953), 181.

74 William of Ockam, "Dialogue on the Power of Pope and Clergy," in A Letter to the Friars Minor and Other Writings, ed. Arthur Stephen McGrade (Cambridge: Cambridge University Press, 1995), 123.

75 Ockham, "Dialogue on the Power of Pope and Clergy," 125.

76 Dante, On Monarchy, ed. D. Nicholl (London: Weidenfeld and Nicolson, 1954), 11.

77 Dante, Monarchy, 14.

78 Ockam, Dialogue on the Power of Pope and Clergy, 164.

79 Mansfield, Taming the Prince, 266-67. Clinton Rossiter associates Hamilton's notion of executive energy with "confidence, dignity, authority," "getting things done," "strength," as well as the "use of power imaginatively and forcefully in the public interest." Needless to say, this suggests a certain amount of conceptual ambiguity. Unfortunately, the ambiguity is probably Hamilton's. See Alexander Hamilton and the Constitution (New York: Harcourt, Brace \& World, 1964), 21, 83, 162-3, 189, 252. 
Hamilton's argument that executive energy is indispensable to the "movement" and efficient operations of government mirrors earlier Absolutist associations of the king with the sun, constant motion, or perpetual activity, ${ }^{80}$ or even medieval descriptions of the monarch as a directing force, akin to "what the soul is to the body and what God is to the universe," an "active power" somehow "analogous to the heart." 82

To be sure, in sharp contradistinction to such royalist predecessors, Hamilton accepted the inevitability of a powerful elected representative legislature, while professing a fidelity to fundamental republican principles they do not share: ${ }^{83}$ conventional royalist argument are restated by applying them to the composition of executive power, but hardly the operations of political authority as a whole. What for traditional Christian monarchists were chiefly ideas about the basic principles of political legitimacy (and the virtues of one-person rule) become, in Hamilton's hands, chiefly institutional and organizational arguments about the proper nature of the executive.

However, normative ideas of legitimacy and institutional ideas about their realization are sometimes hard to distinguish; throughout the history of political thought, they have been conflated. Did Hamilton contribute to the preservation of more than the mere outward trappings of earlier monarchist ideas in his defense of the U.S. presidency? Did U.S.style presidentialism -Hamilton's legacy not only to later generations of U.S. citizens, but

80 Francis D. Wormuth, The Royal Prerogative, 1603-49 (Ithaca: Cornell University Press, 1939), 8. Paul Kleber Monod, The Power of Kings: Monarchy and Religion in Europe, 1589-1715 (New Haven: Yale University Press, 1999), 77-8.

81 Aquinas, "On Princely Government," in Selected Political Writings, ed. A.P. d'Entreves (Oxford: Blackwell, 1954), 67

82 Marsilius of Padua, Defensor Pacis, trans. Alan Gewirth (Toronto: University of Toronto Press, 1967), 67.

83 A letter penned by Hamilton to Washington on July $30^{\text {th }} 1792$ is particularly interesting on this score. While responding to criticism of his monarchist impulses, Hamilton admits that " [a] very small number (not more than three or four) [of delegates at the Philadelphia Convention] manifested theoretical opinions favourable in the abstract to a constitution like that of Great Britain, but every one agreed that such a constitution except as the general distribution of departments and powers was out of the Question in reference to this Country. The Member who was most explicit on this point (A Member from New York [surely Hamilton himself]) declared in strong terms that a republican theory ought to be adhered to in this Country as long as there was any chance of its success -that the idea of perfect equality of political rights among the citizens, exclusive of all permanent or hereditary distinctions, was of a nature to engage the good wishes of every good man, whatever might be his theoretic doubts...and that the endeavour ought then to be to secure it to a better chance of success by a government more capable of energy and order" (Hamilton, Writings, 783). Even if we ignore Hamilton's attempt to downplay the enthusiastic monarchist tones of his 1787 Convention speech, it is interesting that he still admits that his (presidentialist) model of the separation of powers builds directly on his (idealized) interpretation of the British Constitution's "general distribution of departments and powers." By implication, Hamilton might be read as conceding that the U.S. presidency builds on the British (monarchical) executive. It is also interesting that Hamilton reiterates his view that his programmatic agenda might be accomplished within a "republican" structure, here characterized by a commitment to equal political rights and concomitant hostility to hereditary or permanent political privilege. Hamilton conveniently drops any reference to his June 1787 advocacy of an "elected monarch," which arguably is the linchpin of Hamilton's uneasy mix of monarchist and republican ideas: the U.S. presidency would rest on the republican principle of free elections and equal political rights, but it nonetheless would be modeled in accordance with key facets of the British crown in order to assure the "energy and order" only monarchy hitherto had achieved. 
to people in Latin and South America and elsewhere as well- end up reproducing noteworthy leftovers from traditional monarchy? Or have I merely recalled some curious but ultimately insignificant conceptual analogies between monarchist political thought and the "unitary" presidentialist executive?

\section{Modern Presidentialism, Charisma, and the Legacy of European Monarchy}

Contemporary presidentialism provides reason enough to worry that Hamilton helped import monarchical elements into modern liberal democracy. ${ }^{84}$ One immediately thinks of the pomp which shrouds executive power especially in presidential regimes, leading journalists to reconstruct inchoate statements of chief executives so as to give them greater authority, and university administrators to ban legitimate peaceful protest on the ground that it might prove insulting to the dignity of the presidency. ${ }^{85}$ Elite and public deference to the president, as well as his remoteness from everyday life, at the very least seem to echo the monarchical past, as does so much present-day political ceremony and symbolism. Yet it remains unclear whether such vestiges of what even the monarchist Bolingbroke mocked as the "unlawful presumption to look their kings in the face" is congruent with a system of government whose legitimacy relies on the free and unhindered thematization and discussion of increasingly complex political and social questions. To the extent that executive recourse to traditionalistic leftovers of monarchical power risks serving as an impediment to effective public oversight of decision making and fundamental government operations, it conflicts directly with modern democratic ideals. The basic dilemma is especially acute in the case of executive secrecy, whose virtues Hamilton defends in Federalist 70 and Federalist 75 as a necessary supplement to the executive's privileged position in foreign policy making. ${ }^{86}$ Prior to Hamilton, of course, the need for executive secrecy had been a stock argument in early modern defenses of (typically monarchical) executive power at least since Machiavelli. Not surprising perhaps, Hamilton is never able to explain adequately in The Federalist how such secrecy ultimately coheres with the popular accountability of executive

84 As Juan Linz notes, "all presidential democracies were inspired by the U.S. model" ("Presidential or Parliamentary Democracy: Does It Make a Difference?" 5). Hamilton helped shape the U.S. presidency, though contemporary presidentialism includes some notable elements (for example, plebiscitarianism) alien to Hamilton's model. For a useful conceptualization of the key differences between parliamentary and presidential versions of liberal democracy, see Douglas V. Verney, "Parliamentary Government and Presidential Government," in Parliamentary versus Presidential Government, ed. Arend Lijphart (New York: Oxford University Press, 1992), 31-47.

85 The latter example refers to an incident at Ohio State University, where student opponents of the Iraq Wars were prevented from waving anti-war banners at a large meeting otherwise open to them.

86 Federalist 70, 424; Federalist 75, 452-53. 
power he otherwise endorses. This unresolved conceptual tension in Hamilton's thinking has been reproduced in countless real-life U.S. political struggles between presidents who make endless claims for the necessity of executive secrecy, on the one hand, and legislators as well as broader groups of citizens worried by such assertions of executive privilege, on the other hand.

Presidents are able to gain possession of a "very different aura" than prime ministers in part because popular opinion seems to find in presidents, as it once did in kings, a microcosm of the political order as a whole. ${ }^{87}$ As in the distant past, social and political anxiety apparently leads many to develop a deep emotional identification with the most concrete and seemingly unmediated representative of the political community, namely the single person of the presidency, whose every staged word and action can now be communicated into the recesses of the private abode of even the most apathetic member of the political community to a degree to which his royal predecessors could only have fantasized. In the contemporary U.S. version of this popular ideology, the president alone represents the popular will, whereas our numerous elected representatives in Congress -whose organizational complexity, it seems, is inconsistent with the emotionally charged sense of identity with a concrete personal symbol apparently called for by our anxiety-ridden times- stands for nothing more than particularized "special interests." ${ }^{88}$ The tricky matter of how a single (mortal) person can regularly transcend political divisions, class conflict, and deep racial, ethnic, and gender tensions is rarely addressed by proponents of this view. In the same spirit, the U.S. president's power of "commander-in-chief" is now understood by significant segments of the populace, elite opinion makers, and of course the president himself, to include a vast range of powers which the U.S. framers clearly did not have in mind. ${ }^{89}$ In the monarchical epoch that only ended two centuries ago, people looked to the concrete person of the king to guard them from a host of foreign and domestic dangers; in present-day presidential regimes, they look to the president to do so. ${ }^{90}$ The organizational conception of a "unitary" executive is thereby confused with a (problematic) model of political legitimacy, according to which the unitary person of the president represents the most direct stand-in for the (unified) political community as a whole.

Research on the institutional dynamics of presidential government corroborates these initial anxieties. Admittedly, much of this literature underscores the plebiscitary character

87 Linz, "Presidential or Parliamentary Democracy: Does It Make a Difference?" 6.

88 In his analysis of Bonapartism, Karl Marx anticipated this development. See The $18^{\text {th }}$ Brumaire of Louis Bonaparte (New York: International, 1963), 32-33.

89 Louis Fisher, Presidential War Power (Lawrence: University of Kansas Press, 1995); Harold Hongju Koh, The National Security Constitution (New Haven: Yale University Press, 1990).

90 Recall Weber's suggestive observation that appeals to charismatic authority typically surface "in times of psychic, physical, economic, ethical, religious, political distress" (From Max Weber: Essays in Sociology, ed. Hans Gerth and C. Wright Mills [New York: Oxford University Press, 1946], 245). 
of modern presidentialism as a main source of its ills. To the extent that Hamilton himself was no supporter of a directly elected president, it would be unfair to interpret them as immediate offshoots of his model of executive power. ${ }^{91}$ Nonetheless, one of their key institutional sources remains the quintessentially Hamiltonian insistence on the need for a strong and independent executive, outfitted with impressive institutional resources, and thus able to compete effectively for power against popularly elected legislatures.

Like their royal predecessors, modern presidents possess an awesome array of administrative and rule-making powers whose legal basis remains at best ambiguous. ${ }^{92}$ In the United States, for example, presidential emergency power has reached stunning proportions, and the executive has garnered prerogative authority at least as far-reaching in scope and impact as those of many pre-democratic monarchs. ${ }^{93}$ As Bruce Ackerman reminds us, this trend in part derives from the immanent institutional operations of presidential regimes based on a traditional vision of the separation of powers, where the "ongoing competition between House, Senate, and Presidency for control over the administrative apparatus has created an excessively politicized style of bureaucratic government, transforming the executive branch into an enemy of the rule of law." ${ }^{4}$ Where the legislature and executive possess independent sources of electoral legitimacy, but are dominated by different parties, for example, the more likely the president will be tempted to pursue his agenda via highly creative interpretations of "whatever-laws-happen-to-be-on-the-books," or by outright executive fiat or decree. ${ }^{95}$ The pressures of political time -the president may realize that his party is about to lose a tenuous majority in the legislature, for example- exacerbate this trend. Zero-sum power rivalry between the executive and its institutional rivals often heightens the probability of lawlessness or even disorder, pace Hamilton's claim that only a presidential system can realize stability and permanence. ${ }^{96}$

The "cult of personality" also represents a special danger in presidential regimes. Especially in winner-take-all systems, campaigns in presidential systems tend to focus on personality and not substantive programs or ideas, while polarizing political deliberation (one is either for or against a particular candidate) in a highly personalized manner. Of course, personalistic politics is found in both parliamentary and presidential systems. In parlia-

91 In order to understand the plebiscitary character of the U.S. presidency, an analysis of its evolution after the founding (with special focus on Andrew Jackson) is necessary. Unfortunately, that important task would take us beyond the confines of this essay.

92 Phillip J. Cooper, By Order of the President: The Use and Abuse of Executive Direct Action (Lawrence: University of Kansas Press, 2002); Kenneth R. Mayer, With the Stroke of a Pen: Executive Orders and Presidential Power (Princeton: Princeton University Press, 2001).

93 On the contemporary situation, see Andrew Rudalevige, The New Imperial Presidency: Renewing Presidential Power After Watergate (Ann Arbor: University of Michigan Press, 2005).

94 Ackerman, "The New Separation of Powers," 641.

95 Ackerman, "New Separation of Powers," 712.

96 Linz, "Presidential or Parliamentary Democracy: Does it Matter?" 18. 
mentary systems, however, a number of formal and informal devices typically operate to minimize the universal specter of the "politics of personality," whereas presidential systems generally encourage aspiring politicians to "strut high above the political plane inhabited by ordinary mortals" in order to justify their sole possession of the "absolute preeminence" that the office of the president suggests. ${ }^{97}$ How better to appeal successfully to an electorate consisting of a mind-boggling diversity of conflicting interests, and thereby gain an impressive independent basis of political power? In presidential systems the universal trend towards personalistic politics is more likely to culminate in assertions of extraordinary or charismatic ability. As Weber noted many decades ago, presidentialism and the quest for leaders who possess exceptional and even superhuman traits appear to go hand-in-hand. The plebiscitary character of the presidential executive remains the immediate source of such trends. Yet they still echo Hamilton's quest to salvage core features of kingship -for example, the belief that our rulers represent "superior beings"- without the institutional trappings of traditional hereditary monarchy.

The present-day obsession with executive charisma can be interpreted as an understandable, albeit highly problematic, quest to grapple with the basic tensions of modern executive power as bequeathed to us by Hamilton and his immediate intellectual predecessors. ${ }^{98}$ For traditional defenders of a divinely sanctioned monarch, attributing awesome decision making tasks to the king made sense given their belief in his religiously based magical or supernatural qualities. ${ }^{99}$ Monarchs were outfitted with vast power because they were thought to possess divinely ordained wisdom and prudence lacking in the remainder of humanity. Indeed, precisely those special powers granted the U.S. executive, in part because of Hamilton's intervention in 1787, can be traced to the belief, widely shared well into the seventeenth and eighteenth centuries, that the divinely constituted wisdom of the monarch was needed as a corrective to irrepressibly flawed (human) lawmaking and adjudication. From a traditional perspective, kings deserved a veto over legislation because their superior wisdom and prudence left them best suited to overrule the errors of the alltoo-human actors who occupied other political and administrative posts. The royal power to pardon was similarly advantageous because the "superior being" of the king alone was

97 Ackerman, "The New Separation of Powers," 661. In a parliamentary system, the governing party's backbenchers "will turn with sudden ferocity when the polls reveal that their leader's personality has become a permanent liability. Better to dump the guy immediately and replace him with somebody who will present the party's program with a more pleasing face at the next election. Even so dominating a persona as Margaret Thatcher found that British backbenchers were utterly ruthless once polls revealed that the Iron Lady had become an obstacle to future success" (658).

98 To the extent that Weber sees "a particularly important case of the charismatic legitimation of institutions" in the "rise of kingship," while simultaneously suggesting a special relationship between presidentialism and charismatic rule, he draws a close conceptual link between (charismatic) kings and their modern successor, the plebiscitary president (Weber, Economy and Society, 241, 266-69, 1141-42, 1451-62).

99 This is a complicated historical and conceptual story with many twists and turns. 
alone suited to compensate effectively for the rigidity and inadequacies of written law. Who better to intervene in the courts in order to make sure that justice is done in the individual case than a divinely sanctioned king? ${ }^{100}$ In medieval English political thought, for example, the king was nothing less than a divinely inspired "fountain of justice," and thus it was his duty to apply the "vigorous hand of the king" in order to provide for the "administration of justice," understood in suitably broad terms, when either parliament or the courts failed to do so to his satisfaction. ${ }^{101}$ Of course, the history of the concept of prerogative is complex. ${ }^{102}$ Yet prerogative was clearly associated with the notion that the cognitive and moral superiority of kings required outfitting them with far-reaching authority to act beyond the normal confines of the law. ${ }^{103}$ Obvious dangers inhered in the practice of royal prerogative, yet for its defenders, the innumerable virtues of placing substantial authority in divine royal hands easily outweighed them.

As noted above, by the end of the eighteenth century, ideas of divine right seemed implausible to sophisticated European political thinkers otherwise sympathetic to monarchical rule. Nonetheless, many of them, including Hamilton, considered it essential that core elements of monarchy be preserved, even if it was no longer possible on the basis of divine right. Accordingly, Hamilton in The Federalist aggressively defends those facets of the proposed U.S. presidency, including the executive veto and pardon power, most clearly inspired by a stylized vision of the British crown. Yet he simultaneously struggles to transcend their original intellectual moorings. When arguing against critics of his proposed executive veto, he notes that

the propriety of a negative has, upon some occasions, been combated by an observation that it was not to be presumed a single man would possess more virtue and wisdom than a number of men; and that unless this presumption should be entertained, it would be improper to give the executive magistrate any species of control over the legislative body. ${ }^{104}$

Hamilton dismisses this criticism, claiming that the executive veto need not rest on traditional ideas about the superior virtue and wisdom of a single person. His defense of the

100 Probably inspired by Aristotle's discussion of kingship and the law, this is also a central theme in medieval defenses of monarchy. For example, see John of Salisbury, Policraticus, 47; Marsilius of Padua, Defensor Pacis, 56-8. The need for (divine) royal "equity" is closely linked to the pardon power; it is also revealing that Blackstone considers both the royal veto and pardon power as examples of royal "prerogative" (Blackstone, Commentaries, 243-44). In short, these distinct features of royal authority were intimately connected in the traditional view, since they all rested on the need for the intervention of the "superior" person of the king.

101 Hanson, From Kingdom to Commonwealth, 72-73, 93, 101. Also, on the common law and royal discretion, see Charles Ogilvie, The King's Government and the Common Law, 1471-1641 (Oxford: Blackwell, 1958).

102 See Hanson, From Kingdom to Commonwealth; Wormuth, The Royal Prerogative.

103 Scigliano, “The President's 'Prerogative Power," 236-44; Wormuth, The Royal Prerogative; Ogilvie, The King's Government.

104 Federalist 73, 443. 
power to pardon in Federalist 74 follows a similar path, making no reference to its original religious foundations while asserting that the unitary character of executive power leaves it most likely to exercise the pardon power in a cautious and responsible fashion. ${ }^{105}$

As many of Hamilton's critics have rightly observed, however, his attempt to place traditional royal powers such as the veto and pardon on a new intellectual footing too often leaves something to be desired. For example, he defends the veto by arguing that "the oftener the [legislative] measure is brought under examination, the greater the diversity in the situations of those who are to examine it, the less must be the danger of those errors which flow from want of due deliberation." 106 Yet it remains unclear why this otherwise plausible general observation about political decision making necessarily justifies an executive veto and not any of a host of conceivable alternative institutional mechanisms capable of increasing "the diversity in the situations of those who examine" proposed legislation. In a similar vein, it is telling that the Hamiltonian model of the pardon power has been widely rejected by U.S. state governments: despite his claim that the unitary executive's "sole fiat would naturally inspire scrupulousness and caution," in fact "sole fiat" here has been exploited by chief executives at both the national and state level to take care of political cronies and undermine the basic principle that the powerful should be subject to the same laws as the weak, just as Hamilton's original critics worried. Consequently, numerous state governments have abandoned Hamilton's model, ${ }^{107}$ and the national government arguably has failed to so only because of the limits to constitutional reform posed by Article V.

Although unmoved by religiously inspired justifications for monarchy, Hamilton helped establish an institution in some crucial respects modeled on the powerful monarchs idealized throughout the history of the Christian West. The resulting paradox should be clear: while implicitly drawing on traditional religious predecessors in constructing the modern presidential executive, he is forced to abandon classical justifications for executive power still available to them. The presidentialist version of the modern executive is outfitted with an enviable set of powers and privileges, yet it no longer would be able to appeal to divine sanction in order to ground them. If the preceding considerations are correct, Hamilton may have been less successful in providing a sturdy foundation for those powers than often believed, at least within the overly deferential context of U.S. scholarship about the "founding fathers." Either Hamilton implicitly relies on problematic reformulations of traditional religiously inspired ideas of kingship (for example, his dependence on the somewhat mysterious notion of executive energy), or his own indisputably secular

105 Federalist 74, 447-49.

106 Federalist 73, 443.

107 For the details, see John Dinan, "The Pardon Power and the American State Constitutional Tradition," Polity 35 (2003): 389-418. 
arguments (his defense of the executive veto, for example) prove unsatisfactory or at least incomplete.

This implies that since its inception, presidentialism has faced a legitimacy deficit. In accordance with Hamilton's wishes, we grant vast powers to our presidents and expect them to use those powers effectively. As Locke anticipated in the Second Treatise, liberal democracy has repeatedly allowed "god-like princes" ample opportunities to "enlarge their prerogative as they pleased." 108 Yet we long ago surrendered the belief in divine sanction and royal magic once indispensable to the justification of "god-like princes." Of course, the increasingly plebiscitary character of the modern executive has helped provide it with new sources of democratic legitimacy. Plebiscitary, as evinced most clearly by the general trend towards the direct election of the president, arguably constitute the most important modern attempt to overcome the presidential executive's original legitimacy deficit. Yet is there any plausible reason to believe that a democratically legitimated leader will be able successfully to fill the shoes of the divinely inspired magical kings to whom we once trusted so much power? As our dominant conceptions of democracy become increasingly secular in character, this possibility necessarily seems more and more remote. Is it any surprise that modern presidential democracy has been characterized by an incessant search for functional replacements for the divine sanction that once justified executive power and privilege? Does not the obsession with presidential charisma -in essence, a secularized version of the religiously grounded magic once attributed to their royal predecessors- then not make sense as an attempt both to explain and justify the awesome powers of the modern presidency? The fact that the institutional structures of presidential democracy force aspiring political leaders to demonstrate that they can "strut high above the political plane of ordinary mortals" might then be interpreted as a useful innovation for making sure that it generates the requisite functional replacement for divine sanction.

However, if one is understandably skeptical of claims to magic or personal charisma in our disenchanted age, or even if one simply worries that a political system unduly dependent on them is unlikely to perform well in the face of the stunning political and social tasks of the new century, a very different -and far more critical- view of presidential democracy seems in order. Then it might be time to acknowledge the improbability of gaining transcendent "superior beings" in positions of leadership, and the right moment as well to reshape the office of the executive in accordance with a more realistic view of its likely holders in an era without gods or kings.

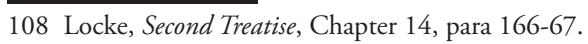

